\title{
PENERAPAN MODEL PEMBELAJARAN BERBASIS MASALAH UNTUK MENINGKATKAN KEMAMPUAN MEMECAHKAN MASALAH KELAS VII SMPN 6 KOTA BENGKULU
}

\author{
Try Liayunika ${ }^{1 *}$, Irawati Sri ${ }^{1}$, Yennita ${ }^{1}$ \\ ${ }^{1}$ Program Studi Pendidian Biologi, Fakultas Keguruan dan Ilmu Pendidikan, Universitas Bengkulu \\ Email: tryliayunika@yahoo.co.id
}

\begin{abstract}
Abstrak
Penelitian ini bertujuan untuk mendeskripsikan penerapan model Pembelajaran Berbasis Masalah yang dilakukan guru dan kemampuan memecahkan masalah peserta didik kelas $\mathrm{VII}_{\mathrm{E}} \mathrm{SMP}$ Negeri 6 Kota Bengkulu. Jenis penelitian adalah penelitian tindakan kelas dengan metode deskriptif. Penelitian terdiri dari dua siklus, setiap siklus terdiri dari 4 tahap yaitu tahap perencanaan, pelaksanaan, pengamatan dan refleksi. Subyek penelitian ini adalah guru dan seluruh peserta didik kelas $\mathrm{VII}_{\mathrm{E}} \mathrm{SMP}$ Negeri 6 Kota Bengkulu. Variabel penelitian adalah model Pembelajaran Berbasis Masalah dan Kemampuan Memecahkan Masalah. Teknik pengumpulan data dalam penelitian ini yaitu observasi dan tes. Instrument penelitian yang digunakan adalah lembar observasi dan lembar tes. Hasil analisis data aktivitas guru siklus I diperoleh skor rata-rata yaitu 25,5 (Baik), dan pada siklus II skor aktivitas guru menjadi 30 (Baik). Hasil analisis data aktivitas peserta didik pada siklus I diperoleh skor rata-rata 25,5 (Baik), dan pada siklus II skor aktivitas peserta didik menjadi 30 (Baik). Data hasil kemampuan peserta didik memecahkan masalah pada siklus I dianalisis berdasarkan kategori ketuntasan belajar klasikal dan diperoleh persentase ketuntasan belajar klasikal yaitu $61 \%$ yang termasuk dalam kategori belum tuntas dan pada siklus II kemampuan peserta didik memecahkan masalah mengalami peningkatan dengan ketuntasan belajar klasikal yaitu $85 \%$ dan termasuk dalam kategori tuntas. Dari hasil penelitian dapat disimpulkan bahwa model Pembelajaran Berbasis Masalah dapat meningkatkan kemampuan peserta didik memecahkan masalah.

Kata kunci: Pembelajaran berbasis masalah, kemampuan memecahkan masalah, pencemaran lingkungan.
\end{abstract}

\begin{abstract}
This research purposed to described the implementation of Problem Based Learning model by teacher and problem solving skill of students at class $\mathrm{VII}_{\mathrm{E}} \mathrm{SMP}$ Negeri 6 Kota Bengkulu. The methodology used in this study was classroom action research with descriptive method. This research consists of two cycles, each cycle consists of 4 stages, that were planning, implementing, observing and reflecting. The subjects of this study were students in class VII $\mathrm{EMP}$ Negeri 6 Kota Bengkulu. The variable from this research were Problem Based Learning model and the problem solving skill of students. Data were collected by observating and testing. The research instrument used was observation sheet and test sheet. The results of data analysis of teacher activity in first cycle obtained average score 25,5 (Good), while in second cycle the teacher activity score was increased to 30 (Good). The result of data analysis of student activity on first cycle obtained average score 25,5 (Good), while in second cycle the student activity score was increased to 30 (Good). The data of the problem solving skill in first cycle was analyzed based on the classical learning completeness category, thas was $61 \%$ which included in incompleteness category. While in the second cycle the problem solving skill of studens had increased to $85 \%$, which was good criteria of classical learning completeness. It was concluded that problem based learning model can improve problem solving skill of students.
\end{abstract}

Keywords: Problem based learning, problem solving skills, environmental management 


\section{PENDAHULUAN}

Ilmu Pengetahuan Alam (IPA) berkaitan dengan cara mencari tahu tentang alam secara sistematis, sehingga IPA bukan hanya penguasaan kumpulan pengetahuan yang berupa fakta-fakta, konsep-konsep, atau prinsip-prinsip saja tetapi juga merupakan suatu proses penemuan. Salah satu tujuan mata pelajaran IPA dalam Kurikulum 2013 menegaskan bahwa peserta didik diharapkan mampu mengembangkan kemampuan bernalar dalam berpikir analisis induktif dan deduktif dengan menggunakan konsep dan prinsip IPA untuk menjelaskan berbagai peristiwa alam dan menyelesaikan masalah baik secara kualitatif maupun kuantitatif. IPA diperlukan dalam kehidupan sehari-hari untuk memenuhi kebutuhan manusia melalui pemecahan masalah-masalah yang dapat diidentifikasi. Penerapan IPA perlu dilakukan secara bijaksana untuk menjaga dan memelihara kelestarian lingkungan. Dengan demikian keterampilan peserta didik dalam memecahkan masalah perlu dilatih pada setiap pembelajaran IPA (Permendikbud Nomor 58, 2014).

$$
\text { Menurut Gunantara }
$$

kemampuan pemecahan masalah adalah proses yang ditempuh oleh seseorang untuk menyelesaikan masalah yang dihadapinya sampai masalah itu tidak lagi menjadi masalah baginya. Kemampuan memecahkan masalah terdiri dari 3 indikator yang dirangkum berdasarkan kemampuan memecahkan masalah pada tingkat SMP, yakni : 1) kesadaran terhadap permasalahan yang akan di pecahkan; 2) permasalahan di pecahkan berdasarkan wawasan dan pengalaman; 3) menjelaskan hubungan antara pengalaman dengan konsep pembelajaran. Indikator kemampuan memecahkan masalah ini dirujuk dari indikator berpikir kritis menurut Ennis (1985) dalam Asrati (2017).
Berdasarkan hasil observasi dan wawancara dengan guru IPA di kelas $\mathrm{VII}_{\mathrm{E}}$ SMP Negeri 6 Kota Bengkulu, diperoleh informasi bahwa kemampuan memecahkan masalah peserta didik masih rendah yaitu hanya mencapai $61 \%$. Kriteria Ketuntasan Minimal (KKM) di SMP Negeri 6 Kota Bengkulu yaitu jika peserta didik mendapat nilai $\geq 70$ dan suatu kelas dapat dikatakan tuntas belajarnya (ketuntasan klasikal) jika $\geq 70 \%$ peserta didik dapat mencapai batasan nilai KKM tersebut. Hal ini berarti kemampuan memecahkan masalah peserta didik belum mencapai kriteria ketuntasan yang ditetapkan di SMP Negeri 6 Kota Bengkulu.

Beberapa peserta didik masih mengalami kesulitan dalam menyelesaikan masalah, peserta didik tidak mampu berfikir dan menghubungkan setiap data yang mereka peroleh, peserta didik hanya terpaku dengan buku dan tidak mampu mengembangkan pola pikir mereka dalam menyelesaikan masalah. Hal ini dikarenakan kurangnya keterlibatan peserta didik dalam proses memecahkan masalah-masalah yang diambil dari kehidupan nyata mereka dan mengaitkannya dengan materi pembelajaran.

Salah satu usaha untuk meningkatkan kemampuan memecahkan masalah dalam pembelajaran IPA biologi di kelas VIIE SMP Negeri 6 Kota Bengkulu adalah dengan menerapkan model Pembelajaran Berbasis Masalah. Menurut Trianto (2014), Pembelajaran Berbasis Masalah merupakan sebuah model pembelajaran yang menyajikan berbagai permasalahan nyata yang penyelesaiannya membutuhkan kerjasama diantara peserta didik dalam memecahkan suatu masalah yang telah disepakati. Menurut Rusman (2014) PBM memfasilitasi keberhasilan memecahkan masalah, komunikasi, kerja kelompok, dan keterampilan interpersonal dengan lebih baik dibanding pendekatan 
lain. Oleh sebab itu diharapkan model PBM dapat lebih unggul dari model pembelajaran yang lain, karena model PBM memfokuskan peserta didik dapat memecahkan masalah dengan cara mereka sendiri.

Berdasarkan data dan informasi di atas, maka peneliti bekerjasama dengan guru mata pelajaran IPA di SMP Negeri 6 Kota Bengkulu untuk melakukan perbaikan pembelajaran IPA dikelas $\mathrm{VII}_{\mathrm{E}}$ dengan menerapkan model Pembelajaran Berbasis Masalah pada materi Pencemaran Lingkungan melalui PTK untuk meningkatkan kemampuan memecahkan masalah pada peserta didik.

\section{METODE}

Penelitian ini merupakan Penelitian Tindakan Kelas (PTK) dengan metode deskriptif yang dilakukan dalam 2 kali siklus. Setiap siklus terdiri dari tahap perencanaan, pelaksanaan, pengamatan dan refleksi. Penelitian dilaksanakan pada semester genap tahun ajaran 2017/2018 di SMPN 6 Kota Bengkulu. Peran peneliti dalam penelitian ini adalah sebagai guru IPA Biologi yang mengajar peserta didik pada materi Pencemaran Lingkungan. Subjek penelitian yaitu peserta didik kelas VIIE SMPN 6 Kota Bengkulu berjumlah 33 peserta didik yang terdiri dari 18 laki-laki dan 15 perempuan.

Teknik pengumpulan data dalam penelitian ini adalah observasi dan tes. Instrumen yang digunakan berupa lembar observasi aktivitas guru dan aktivitas peserta didik serta lembar tes kemampuan memecahkan masalah. Lembar observasi digunakan untuk mengamati kegiatan guru dan aktivitas peserta didik dalam proses pembelajaran pada materi pencemaran lingkungan menggunakan model Pembelajaran Berbasis Masalah (PBM). Lembar tes digunakan untuk mengumpulkan data kemampuan memecahkan masalah peserta didik.
Lembar tes pemecahan masalah terdiri dari soal-soal uraian yang digunakan untuk mengukur kemampuan memecahkan masalah. Soal-soal uraian pada lembar tes dirumuskan berdasarkan indikator kemampuan memecahkan masalah yang telah ditentukan dalam penelitian ini, yaitu: 1) kesadaran terhadap permasalahan yang akan di pecahkan; 2) permasalahan di pecahkan berdasarkan wawasan dan pengalaman; 3) menjelaskan hubungan antara pengalaman dengan konsep pembelajaran (Ennis, 1985) dalam (Asrati, 2017).

Data hasil observasi aktivitas mengajar guru dan belajar peserta didik dianalisis secara deskriptif dengan cara mencari rata-rata dan rentang kategori. Rumus yang digunakan adalah:

$$
\bar{X}=\frac{\sum X}{N} \quad \text { (Winarsunu, 2015) }
$$

Keterangan:

$\bar{X}=$ Rata-rata

$\sum X=$ Jumlah seluruh skor yang diperoleh

$N=$ Jumlah observer

Penentuan kisaran skor untuk setiap kategori diolah dengan menggunakan rumus berikut:

$$
\text { Kisaran skor= } \frac{\text { skor tertinggi }- \text { skor terendah }}{\text { iumlah kategori }}
$$

(Sukardi, 2012)

Keterangan :

Skor tertinggi $=$ jumlah butir pengamatan $x$ skor tertinggi setiap butir

Skor terendah =jumlah butir pengamatan $x$ skor terendah setiap butir

Lembar observasi aktivitas guru dan aktivitas peserta didik berjumlah 10 butir pengamatan, skor tertinggi tiap butir 3 dan skor terendah tiap butir 1, maka kategori penilaian untuk lembar observasi aktivitas guru dan aktivitas peserta didik dapat di lihat pada Tabel 1: 
Tabel 1. Kategori penilaian lembar observasi aktivitas guru dan aktivitas peserta didik

\begin{tabular}{cc}
\hline Rentang Skor & Kategori Penilaian \\
\hline $10-16$ & Kurang \\
$17-23$ & Cukup \\
$24-30$ & Baik \\
\hline
\end{tabular}

Data hasil tes kemampuan memecahkan masalah peserta didik diolah secara deskriptif menggunakan rumus rata-rata dan persentase yang digunakan untuk mendeskripsikan hasil kemampuan memecahkan masalah peserta didik dan tingkat keberhasilan peserta didik di dalam proses pembelajaran. Kategori kemampuan memecahkan masalah yang ditetapkan peneliti adalah tuntas dan tidak tuntas. Untuk mengetahui persentase ketuntasan kemampuan peserta didik memecahkan masalah secara keseluruhan menggunakan rumus persentase ketuntasan belajar klasikal. Menurut ketentuan yang ditetapkan di SMPN 6 Kota Bengkulu peserta didik dikatakan tuntas pada mata pelajaran IPA apabila mencapai nilai $K K M \geq 70$. Adapun rumus persentase ketuntasan kemampuan memecahkan masalah peserta didik:

$\mathrm{P}=\frac{\sum X}{N} X 100 \% \quad$ (Widoyoko, 2016)

Keterangan:

$\Sigma \mathrm{X}=$ Jumlah peserta didik berkategori tuntas

$\mathrm{N}$ = Jumlah seluruh peserta didik

$\mathrm{P}=$ Persentase ketuntasan kemampuan memecahkan masalah peserta didik

\section{HASIL DAN PEMBAHASAN}

Berdasarkan hasil penelitian yang telah dilakukan, data hasil observasi aktivitas guru dalam kegiatan pembelajaran dengan model PBM dapat dilihat pada Tabel 2 .

Tabel 2. Aktivitas guru pada pembelajaran model PBM di siklus I dan siklus II

\begin{tabular}{cccc}
\hline \multicolumn{2}{c}{ Siklus I } & \multicolumn{2}{c}{ Siklus II } \\
\hline Rata-rata & Kategori & Rata-rata & Kategori \\
25.5 & Baik & 30 & Baik \\
\hline
\end{tabular}

Rerata skor observasi aktivitas guru pada pembelajaran model PBM di Siklus I yaitu 25.5 dengan kategori baik. Secara keseluruhan tahapan pada proses pembelajaran di siklus I dinilai baik oleh dua pengamat, namun masih terdapat beberapa aspek yang berkategori cukup yaitu pada aspek menjelaskan tujuan PBM, menjelaskan prosedur kegiatan pemecahan masalah, membagi tugas kepada peserta didik mengenai kegiatan yang akan dilakukan dalam menyelesaikan masalah, membimbing kelompok peserta didik pada saat mengaitkan data hasil percobaan dengan konsep, serta membimbing peserta didik untuk menarik kesimpulan berdasarkan kegiatan yang telah dilakukan.

Pada siklus II juga dilakukan observasi terkait aktivitas mengajar guru menggunakan model PBM yang diperoleh dari 2 orang pengamat menggunakan lembar observasi. Berdasarkan hasil observasi aktivitas mengajar guru meggunakan model PBM semua aspek sudah dinilai baik oleh kedua pengamat sehingga rerata skor yang diperoleh lebih meningkat. Langkah/tahap pembelajaran di siklus II semua sudah dinilai baik oleh kedua pengamat karena pada proses pembelajaran di siklus II, guru sudah menjalankan langkah/tahap pembelajaran yang benar dan tepat sesuai dengan tahap model PBM.

Proses observasi aktivitas peserta didik pada pembelajaran model PBM telah dilakukan oleh kedua pengamat dengan memperoleh rerata skor dan kategori skor yang dipaparkan pada Tabel 3 berikut:

Tabel 3. Aktivitas peserta didik pada pembelajaran model PBM di siklus I dan siklus II

\begin{tabular}{cccc}
\hline \multicolumn{2}{c}{ Siklus I } & \multicolumn{2}{c}{ Siklus II } \\
Rata-rata & Kategori & Rata-rata & Kategori \\
\hline 25.5 & Baik & 30 & Baik \\
\hline
\end{tabular}


Rata-rata skor observasi aktivitas peserta didik pada pembelajaran model PBM di Siklus I yaitu 25.5 dengan kategori baik. Hampir keseluruhan observasi aktivitas peserta didik pada pembelajaran model PBM di Siklus I dinilai baik oleh kedua pengamat, namun masih terdapat katergori cukup yang diberikan oleh dua pengamat, yaitu pada aspek memperhatikan dan mencatat tujuan pembelajaran yang dijelaskan oleh guru; memperhatikan saat guru menyampaikan prosedur kegiatan pada Lembar Kerja Peserta Didik (LKPD) yang akan digunakan dalam menyelesaikan masalah; setiap kelompok berbagi tugas kesetiap anggota kelompoknya dalam melaksanakan kegiatan diskusi/percobaan; aktivitas anggota dari seluruh kelompok peserta didik pada saat berdiskusi terkait data hasil diskusi/percobaan dengan konsep; dan aktivitas anggota seluruh kelompok peserta didik pada saat berdiskusi untuk menarik kesimpulan terkait penyelidikan yang telah dilakukan pada materi pencemaran lingkungan.

Pada siklus II rata-rata skor yang diperoleh lebih meningkat dibandingkan dengan siklus I yakni 30 dengan kategori baik. Langkah/tahap pembelajaran di siklus II semua sudah dinilai baik oleh kedua pengamat dan mengalami peningkatan dari siklus I ke siklus II karena pada proses pembelajaran di siklus II, guru sudah menjalankan langkah/tahap pembelajaran yang benar dan tepat sesuai dengan tahap model PBM sehingga aktivitas peserta didik dalam proses pembelajaran juga meningkat.

Berdasarkan penelitian yang telah dilakukan pada siklus I dan II diperoleh hasil rerata skor dan persentase kemampuan peserta didik memecahkan masalah yang dipaparkan pada Tabel 4:
Tabel 4. Nilai rerata dan persentase kemampuan peserta didik memecahkan masalah siklus I dan siklus II

\begin{tabular}{cccc}
\hline Siklus & $\begin{array}{c}\text { Rata-rata } \\
\text { nilai } \\
\text { kemampuan } \\
\text { peserta didik } \\
\text { memecahka } \\
\text { n masalah }\end{array}$ & $\begin{array}{c}\text { Jumla } \\
\mathbf{h} \\
\text { pesert } \\
\text { a didik } \\
\text { yang } \\
\text { tuntas }\end{array}$ & $\begin{array}{c}\text { Persentase } \\
\text { kemampuan } \\
\text { peserta didik } \\
\text { memecahka } \\
\text { n masalah }\end{array}$ \\
\hline I & 68,82 & 20 & $61 \%$ \\
II & 81,14 & 28 & $85 \%$ \\
\hline
\end{tabular}

Berdasarkan analisis data proses pembelajaran yang dilalui selama dua siklus penerapan model PBM pada penelitian ini juga mampu meningkatkan ranah kognitif peserta didik, khususnya kemampuan memecahkan masalah peserta didik kelas VIIE SMP Negeri 6 Kota Bengkulu pada materi pencemaran lingkungan. Model PBM memiliki tahapan yang mengorientasikan peserta didik pada masalah, sehingga peserta didik dituntut untuk berpikir dan berusaha memecahkan masalah yang diberikan oleh guru. Hal ini sesuai dengan penelitian yang dilakukan oleh Valentisari (2016) dan Syafi'i (2011) bahwa sintak atau tahapan pada model PBM dapat melatih peserta didik untuk mengembangkan kemampuan berpikir dalam pemecahan masalah, berpikir kreatif, dan meningkatkan kemampuan memecahkan masalah peserta didik.

Pada siklus I materi Pencemaran Air diperoleh persentase ketuntasan belajar klasikal yaitu $61 \%$ dan dikategorikan belum tuntas. Sedangkan ketuntasan belajar klasikal yang ditentukan oleh sekolah sebesar $70 \%$. Adapun pada siklus II materi Pencemaran Tanah dan Udara mengalami peningkatan menjadi 85\%, sehingga dikategorikan tuntas. Hal ini menunjukkan kemampuan peserta didik memecahkan masalah mengalami peningkatan 
dibandingkan pada pembelajaran sebelumnya yaitu sebesar $24 \%$.

Peningkatan

kemampuan

memecahkan masalah ini salah satunya dikarenakan peserta didik melakukan kegiatan diskusi pemecahan masalah menggunakan pembelajaran berbasis masalah (PBM) yang tercermin pada Lembar Kerja Peserta Didik (LKPD) atau Lembar Diskusi Peserta Didik (LDPD) sehingga peserta didik dapat membangun pengetahuan sendiri dan pembelajaran yang dialami peserta didik akan lebih bermakna. Hal ini sesuai dengan pernyataan Fariroh dkk (2015), bahwa belajar akan lebih bermakna jika peserta didik mengalami apa yang dipelajarinya, bukan sekedar mengetahui materi. Hasil penelitian ini juga diperkuat dengan pendapat Yuniar (2015) bahwa PBM bertujuan untuk membantu peserta didik mengembangkan keterampilan berpikir tingkat tinggi dan basis pengetahuan disiplin substansial dengan menempatkan peserta didik dalam peran aktif baik dalam kelompok maupun individu, dihadapkan dengan situasi yang mencerminkan dunia nyata.

Pada siklus I materi Pencemaran Air, soal yang banyak dijawab benar oleh peserta didik adalah soal no 1 pada indikator kesadaran terhadap permasalahan yang akan dipecahkan. Soal no 1 berisi materi tentang penyebab pencemaran di selokan, yang banyak dijawab benar oleh peserta didik karena peserta didik dapat menjelaskan penyebab pencemaran di selokan tersebut. Berdasarkan indikator hal ini berarti peserta didik sadar terhadap permasalahan yang akan dipecahkan pada kasus 1.

Soal no 3 merupakan soal yang paling sulit dijawab oleh peserta didik pada siklus I, dengan indikator menjelaskan hubungan antara pengalaman dengan konsep pembelajaran pada sub materi upaya mengurangi pencemaran air. Hal ini dikarenakan peserta didik masih sulit menjelaskan hubungan upaya pencegahan pencemaran air berdasarkan pengalaman peserta didik dengan konsep pembelajaran.

Soal no 2 sebagian dijawab benar oleh peserta didik karena sebagian peserta didik sudah dapat menganalisis pengaruh limbah detergen terhadap ekosistem perairan tersebut, sebagian peserta didik masih sulit memecahkan permasalahan berdasarkan wawasan dan pengalaman. Sehingga diperoleh rata-rata kemampuan peserta didik memecahkan masalah pada siklus I yaitu 68,82. Hal tersebut menandakan bahwa peserta didik kurang memahami soal-soal terkait indikator pemecahan masalah yang mana pertanyaannya lebih tinggi daripada pertanyaan ingatan (C1). Sebagaimana pernyataan Arikunto (2013) bahwa soal pemahaman menuntut peserta didik untuk menghafal suatu pengertian kemudian menjelaskan dengan kalimat sendiri, sehingga dalam menjawab soal pemahaman peserta didik selain harus mengingat juga berpikir.

Kemampuan memecahkan masalah peserta didik mengalami peningkatan setelah dilakukan refleksi pada siklus I. Rerata hasil kemampuan memecahkan masalah pada siklus II materi Pencemaran Tanah dan Udara meningkat menjadi 81,14 , dimana peserta didik sudah dapat menjawab pertanyaan masing-masing indikator pemecahan masalah secara optimal. Walaupun hasil pemecahan masalah peserta didik meningkat, namun masih banyak peserta didik yang masih kurang paham pada soal no 1 di indikator kesadaran terhadap permasalahan yang akan dipecahkan, hal ini dikarenakan beberapa peserta didik hanya menjelaskan pencemaran yang terjadi pada kasus I saja, dan hanya menyebutkan pencemaran yang terjadi dari kedua kasus tersebut tanpa 
menjelaskan alasannya, sehingga skor yang diperoleh peserta didik berkurang.

\section{Peningkatan}

kemampuan

memecahkan masalah peserta didik terjadi karena dilakukannya perbaikan penerapan model PBM di siklus II dengan cara memperbaiki kekurangan yang ada di siklus I yaitu membimbing seluruh kelompok peserta didik (6 kelompok) dalam orientasi masalah, mengorganisasikan peserta didik untuk belajar, membimbing kelompok peserta didik dalam mengaitkan data hasil percobaan dengan konsep/materi, membimbing peserta didik menyimpulkan hasil percobaan serta mempertahankan aspek-aspek yang sudah baik di siklus I. Hal tersebut dikarenakan masing-masing tahap pada model PBM akan mempengaruhi kemampuan memecahkan masalah peserta didik dalam proses pembelajaran, dimana 3 indikator pemecahan masalah akan berkembang pada setiap tahapan model PBM.

Jika setiap tahapan pada model PBM yang dilaksanakan dengan baik, maka peserta didik akan memperoleh hasil kemampuan memecahkan masalah secara optimal, karena masalah yang dihadapkan pada peserta didik berupa masalah dunia nyata yakni yang ditemui dalam kehidupan sehari-hari peserta didik, sehingga dengan adanya permasalahan tersebut maka dapat merangsang proses berpikir peserta didik yang lebih tinggi dalam memecahkan permasalahan. Hal ini sesuai dengan pernyataan Rusman (2014) bahwa model Pembelajaran Berbasis Masalah (PBM) adalah suatu model pembelajaran yang menggunakan masalah dunia nyata sebagai suatu konteks bagi peserta didik untuk belajar tentang cara berpikir kritis dan keterampilan pemecahan masalah serta untuk memperoleh pengetahuan dan konsep yang esensial dari materi pelajaran.

\section{PENUTUP}

\section{Simpulan}

Berdasarkan hasil penelitian, simpulan dalam penelitian ini adalah perbaikan pembelajaran dengan menerapkan model Pembelajaran Berbasis Masalah dalam proses pembelajaran materi pencemaran lingkungan di kelas $\mathrm{VII}_{\mathrm{E}}$ SMP Negeri 6 Kota Bengkulu dapat meningkatkan aktivitas mengajar guru, rata-rata skor aktivitas guru pada siklus I yaitu 25,5 (baik) meningkat disiklus II menjadi 30 (baik) dan meningkatkan ratarata skor aktivitas belajar peserta didik siklus I yaitu 25,5 (baik), meningkat disiklus II menjadi 30 (baik). Selain itu, pembelajaran dengan menerapkan model Pembelajaran Berbasis Masalah dalam proses pembelajaran pada materi pencemaran lingkungan di kelas $\mathrm{VII}_{\mathrm{E}} \mathrm{SMP}$ Negeri 6 Kota Bengkulu dapat meningkatkan kemampuan memecahkan masalah peserta didik. Hal ini dapat dilihat dari nilai rata-rata kemampuan memecahkan masalah peserta didik 68,82 dengan persentase $61 \%$ (belum tuntas) menjadi 81,14 dengan persentase $85 \%$ (tuntas).

\section{Saran}

Berdasarkan penelitian yang telah dilakukan, saran yang perlu dipertimbangkan sebagai tindak lanjut yaitu hendaknya memperhatikan tahap dari model Pembelajaran Berbasis Masalah, terutama pada tahap mengorganisasi peserta didik untuk belajar, guru dituntut untuk menjelaskan secara rinci kegiatan pemecahan masalah yang akan dilakukan sesuai dengan LKPD yang digunakan, sehingga di tahap ini keterampilan menjelaskan perlu ditingkatkan. Bagi peneliti lanjutan agar dapat melakukan penelitian lebih lanjut mengenai kemampuan memecahkan masalah dengan memperhatikan masalah yang akan diberikan kepada peserta didik 
dan tetap melakukan eksperimen di dalam kegiatan pembelajaran.

DAFTAR PUSTAKA

Arikunto, Suharsimi. (2013). Prosedur Penelitian : Suatu Pendekatan Praktik. Jakarta : Rineka Cipta.

Asrati, Sirtika. (2017). Penerapan Model Problem Based Learning pada Materi Pengelolaan Lingkungan untuk Meningkatkan Kemampuan Memecahkan Masalah Peserta didik Kelas VIIc SMPN 9 Kota Bengkulu. Skripsi (Tidak diterbitkan).

Fariroh, Aida dan Anggraito, Yustinus Ulung. (2015). Pengembangan Perangkat Pembelajaran Berbasis Problem Based Learning Pada Materi Virus Kelas $X$ SMA. Semarang: FMIPA Universitas Negeri Malang

Gunantara, G., dkk. (2014). Penerapan Model Pembelajaran Problem Based Learning untuk Meningkatkan Kemampuan Pemecahan Masalah Matematika Siswa Kelas V. Jurnal Mimbar PGSD 2

(http://ejournal.undiksha.ac.id), diakses 21 Juli 2018).

Permendikbud Nomor 58 tahun 2014 tentang Kurikulum 2013 Sekolah Menengah Pertama/Madrasah Tsanawiyah (salinan).

Rusman. (2014). Model-model Pembelajaran. Jakarta: Rajawali Pers.

Sukardi, H.M. 2012. Evaluasi Pendidikan. Jakarta: Bumi Aksara.

Syafi'i, Wan., dkk. (2011). Kemampuan Berfikir Kreatif dan Penguasaan Konsep Peserta didik Melalui Model Problem Based Learning (PBL) dalam Pembelajaran Biologi Kelas XI IPA SMAN 2 Pekan Baru. Jurnal Biogenesis, 8 (1). (http://ejournal.unri.ac.id/rticle/vi ew/1872/1841), diakses 21 Juli 2017.

Trianto. (2014). Mendesain Model Pembelajaran Inovatif, Progresif, dan Kontekstual. Jakarta: Bumi Aksara.

Valentisari, Dewi. (2016). Penerapan Model Pembelajaran Berbasis Masalah Pada Materi Pengelolaan Lingkungan untuk Meningkatkan Kemampuan Memecahkan Masalah Peserta didik Kelas $\mathrm{VII}_{G}$ SMP Negeri 10 Kota Bengkulu. Skripsi tidak diterbitkan. Bengkulu: Program Studi Pendidikan Biologi FKIP Universitas Bengkulu.

Widoyoko, E.P. (2016). Evaluasi Program Pembelejaran. Yogyakarta: Pustaka Belajar.

Winarsunu, Tulus. (2015). Statistik dalam Penelitian Psikologi dan Pendidikan. Malang: Universitas Muhammadiyah Malang.

Yuniar, TE dan Widodo, AT. (2015). Problem Based Learning Berpendekatan Seven Jumps Untuk Meningkatkan Hasil Belajar Peserta didik.(http://journal.unnes.ac.id/sj u/index.php/chemined), diakses 17 april 2018. 